\title{
PERSEPSI GURU PAMONG TERHADAP KUALITAS MAHASISWA CALON GURU PJOK SAAT MELAKSANAKAN PROGRAM PENGELOLAAN PEMBELAJARAN DI SEKOLAH MITRA
}

\author{
Fifukha Dwi Khory ${ }^{1}$, Setiyo Hartoto ${ }^{2}$, Sudarso Sudarso ${ }^{3}$, dan Bayu \\ Budi Prakoso ${ }^{4}$ \\ ${ }^{1,2,3,4}$ Pendidikan Jasmani, Kesehatan, dan Rekreasi \\ Universitas Negeri Surabaya \\ E-mail: fifukhakhory@unesa.ac.id', setiyohartoto@unesa.ac.id², \\ sudarso@unesa.ac.id ${ }^{3}$, bayuprakoso@unesa.ac.id ${ }^{4}$
}

Diterima: 30 April 2018; Lolos: 17 Mei 2018; Dipublikasikan: 18 Mei 2018

DOI: https://doi.org/10.29407/js_unpgri.v4i1.12092

\begin{abstract}
Abstrak
Penelitian ini bertujuan untuk mengetahui kualitas mahasiswa calon guru PJOK saat melakukan Program Pengelolaan Pembelajaran (PPP) di sekolah mitra Unesa. Penelitian ini menggunakan metode penelitian deskriptif kualitatif. Subjek penelitian merupakan volunteer sebanyak 10 orang berstatus sebagai mahasiswa calon guru PJOK saat melaksanakan PPP di sekolah mitra Unesa di kota Surabaya. Kualitas mahasiswa calon guru PJOK dinilai oleh guru pamong terkait tiga hal, yaitu: (1) kelayakan mahasiswa menjadi guru PJOK; (2) kebutuhan kompetensi guru; dan (3) kompetensi mahasiswa sebagai guru praktikkan. Hasil penelitian menunjukkan bahwa nilai rata-rata kelayakan mahasiswa calon guru PJOK menjadi guru praktikkan di sekolah mitra Unesa sebesar 80.5 (sangat layak). Berdasarkan persepsi guru pamong, sekolah memerlukan guru PJOK hebat yang memiliki kemampuan akademik yang mumpuni, menguasai perkembangan kurikulum terbaru, menguasai materi ajar, memiliki keterampilan pengelolaan kelas yang baik, keterampilan memecahkan masalah pembelajaran, kreatif dan inovatif. Sedangkan kualitas kinerja mahasiswa calon guru PJOK dinilai sudah cukup, dianggap telah mampu mengelola kelas, membuat RPP $\mathrm{K}-13$, menguasai teknik mengajar, update pengetahuan tentang $\mathrm{K}-13$, memiliki dedikasi, kemampuan mengembangkan diri tinggi dan disiplin tinggi. Hasil penelitian ini secara sekilas telah mampu mendeskripsikan kualitas mahasiswa dalam mengikuti PPP, akan tetapi jumlah subjek penelitian yang sedikit menjadi batasan dalam proses generalisasi hasil terhadap populasi.
\end{abstract}

Kata kunci: Persepsi guru pamong, profil guru PJOK hebat, kualitas mahasiswa calon guru PJOK, dan program pengelolaan pembelajaran.

\section{SUPERVISING TEACHERS' PERCEPTION OF THE QUALITY OF PROSPECTIVE PHYSICAL EDUCATION TEACHERS IN IMPLEMENTING LEARNING MANAGEMENT PROGRAMIN PARTNER SCHOOL}

\begin{tabular}{l} 
Abstract \\
This study aims to determine the quality of prospective PE teachers (PPET) in \\
implementing learning management program (LMP) in a partner school of \\
Universitas Negeri Surabaya. Descriptive qualitative approach was applied. The \\
\\
\hline Email : bayuprakoso@unesa.ac.id \\
$\begin{array}{ll}\text { No Handphone : } 081331391749 & \text { C2018 UN PGRI Kediri } \\
& \text { p-ISSN: } 2548-7833 \\
\text { e-ISSN: } 2477-3379\end{array}$
\end{tabular}


Fifukha Dwi Khory, Setiyo Hartoto, Sudarso Sudarso, dan Bayu Budi Prakoso

Persepsi Guru Pamong Terhadap Kualitas Mahasiswa Calon Guru PJOK Saat Melaksanakan Program Pengelolaan Pembelajaran di Sekolah Mitra

research subjects were ten PPET who conducted LMP. There were three criteria that would be assessed by the supervising teacher: (1) students' feasibility to become a PE teachers; (2) need of teacher competence; and (3) competence in student teaching. Research findings showed that the average of students' feasibility score as student teachers 80.5 (very feasible). Based on the supervising teacher's perception, the school needs quality teachers who have good academic skills, master the latest curriculum and teaching materials, have good classroom management skills and problem solving, and are creative and inovative. The quality of PPET was sufficient because they were able to manage the class, develop a lesson plan based on the 2013 curriculum, master teaching techniques, know the latest information of the 2013 curriculum, have high selfdevelopment ability, dedication, and discipline. In conclusion, the results of this study were able to describe the quality of PPET in conducting LMP, but this study only had few subjects, the findings might not be able to generalize the whole population.

Keywords: Supervising teachers perception, profile of great PE teachers, quality of prospective $P E$ teachers, learning management program.

\section{PENDAHULUAN}

Program Pengelolaan Pembelajaran (PPP) di sekolah merupakan kesempatan paling berharga bagi mahasiswa untuk mendapatkan pengalaman dalam mengenal lingkungan sekolah dan praktik pembelajaran secara nyata. Selama mengikuti program tersebut, mereka datang ke sekolah mengikuti rutinitas sebagai warga sekolah. Mereka dibimbing untuk menjadi guru yang memiliki kompetensi mumpuni sesuai dengan standar nasional dengan kapasitas mereka sebagai mahasiswa calon guru, yaitu mulai belajar untuk menguasai kompetensi pedagogik, sosial, kepribadian, dan profesional (Indonesian Government, 2005, 2008; Ministry of National Education of Republic of Indonesia, 2007).

Program ini merupakan program unggulan Perguruan Tinggi (PT) untuk memberikan pembekalan kepada mahasiswa untuk mengasah kompetensi mereka menjadi guru. Pelaksanaan PPP di mayoritas PT dibilang sangat singkat, dilaksanakan selama 7 minggu diawal semester ganjil (Juli-september) (Tim PPP, 2017). Padahal, untuk mendapatkan pemahaman yang lebih banyak dalam menentukan kesuksesan PPP dalam melahirkan guru yang efektif, diperlukan durasi waktu yang panjang. Minimal diperlukan 20 pertemuan atau lebih untuk menilai guru berhasil dalam menciptakan pembelajaran yang efektif sesuai dengan 
Fifukha Dwi Khory, Setiyo Hartoto, Sudarso Sudarso, dan Bayu Budi Prakoso

Persepsi Guru Pamong Terhadap Kualitas Mahasiswa Calon Guru PJOK Saat Melaksanakan Program Pengelolaan Pembelajaran di Sekolah Mitra

kurikulum yang berlaku (Ward, 2013). Selain itu, untuk membuat mahasiswa menjadi paham dan mantap dalam memulai mengajar di kondisi nyata melalui pengalaman mengajar, perlu dilakukan program pengalaman lapangan selama 15 minggu (Barney \& Pleban, 2006). Tanpa melihat keterbatasan pelaksanaan PPP, PT dinilai kurang dapat memfasilitasi para mahasiswa dalam mengasah diri untuk mencapai kompetensi yang tinggi. Hal ini semakin menguatkan bahwa PT pantas dikatakan gagal dalam mempersiapkan para mahasiswa untuk menjadi guru yang efektif (Şen, 2010).

Betapapun PT dikatakan gagal dalam memberikan waktu yang cukup kepada mahasiswa dalam mengasah diri di sekolah, PT tetap berusaha membuat waktu yang singkat tersebut menjadi wahana yang efektif dalam membekali mahasiswa untuk mampu beradaptasi di lingkungan sekolah. Walaupun singkat, pelaksanaan PPP selalu dipantau dan didampingi oleh guru-guru pamong yang memiliki kualifikasi cukup dalam membantu mahasiswa dalam belajar mengenal lingkungan belajar di sekolah. Guru pamong selanjutnya bertindak sebagai supervisor utama sekaligus mentor bagi para mahasiswa dalam belajar mengembangkan diri, kompetensi, dan profesionalisme (Fransson \& K. McMahan, 2013). Proses supervisi terhadap kualitas mahasiswa PPP menjadi kunci utama untuk memberikan masukan-masukan penting dalam mempertinggi kualitas pembelajaran yang diciptakan oleh mahasiswa (Marli, 2011).

Di sisi lain, manfaat yang diberikan oleh kegiatan PPP tidak hanya didapatkan oleh mahasiswa, akan tetapi para guru pamong dapat mengembangkan diri melalui kegiatan peninjauan mutu profesi diri mereka dan berkontribusi dalam mempersiapkan para calon guru menjadi guru hebat (Faikhamta \& Clarke, 2018). Artinya, kolaborasi yang terjadi antara mahasiswa dan guru pamong dalam kegiatan PPP menjadi ajang evaluasi keprofesionalan guru dalam meningkatkan kompetensi.

Melihat berharga dan singkatnya waktu pelaksanaan PPP, akan sangat disayangkan apabila kegiatan PPP hanya dianggap sebagai matakuliah wajib ditempuh oleh mahasiswa tanpa dimanfaatkan secara 
Fifukha Dwi Khory, Setiyo Hartoto, Sudarso Sudarso, dan Bayu Budi Prakoso

Persepsi Guru Pamong Terhadap Kualitas Mahasiswa Calon Guru PJOK Saat Melaksanakan Program Pengelolaan Pembelajaran di Sekolah Mitra

optimal. Mahasiswa PPP memiliki banyak kesempatan dalam memperdalam keilmuan tentang pembelajaran dengan berkolaborasi dengan guru pamong tentang topik utama PPP, seperti strategi pengajaran, proses belajar mengajar, dan pengembangan kompetensi (Helgevold, Næsheim-Bjørkvik, \& Østrem, 2015). Keberhasilan pelaksanaan PPP menjadi penting diketahui melalui kegiatan supervisi oleh guru pamong, sehingga mahasiswa mendapatkan gambaran kelayakan mereka untuk dapat menjadi guru di sekolah, tuntutan sekolah terhadap kompetensi guru, dan mendapatkan gambaran kualitas kompetensi yang dimiliki. Kegiatan supervisi pelaksanaan PPP dapat membantu PT dalam mengukur output para calon guru yang mereka didik melalui proses perkuliahan. Untuk itu, artikel ini berusaha mencapai tiga tujuan tersebut agar pelaksanaan PPP dapat memberikan masukan yang bermakna dalam membangun kompetensi mahasiswa calon guru PJOK.

\section{METODE}

Penelitian ini termasuk dalam penelitian deskriptif yang berusaha untuk menjelaskan kualitas mahasiswa berdasarkan penilaian yang dilakukan oleh guru pamong saat melakukan PPP yang bersifat kualitatif. Pelaksanaan PPP dilakukan di sekolah mitra Unesa di tingkat SMP dan SMA yang ada di kota Surabaya selama bulan Juli-September 2017.

\section{Subjek Penelitian}

Subjek penelitian ini adalah 10 mahasiswa calon guru PJOK (3 perempuan dan 7 laki-laki), 3 orang mengikuti PPP di tingkat SMP, dan 7 orang mengikuti PPP di tingkat SMA. Seluruh mahasiswa calon guru PJOK yang menjadi subjek penelitian adalah mereka yang kuliah di Unesa tahun 2014 atau sudah memasuki tahun ke-4.

\section{Instrumen Penelitian}

Instrumen yang digunakan adalah kuesioner tertutup dan terbuka. Kuesioner tertutup digunakan untuk menentukan kelayakan dengan menggunakan aturan penilaian kelayakan menggunakan skala respon ekspektasi (Bandura, 2006) dengan rentang nilai 0-100 (lihat gambar 1). 
Fifukha Dwi Khory, Setiyo Hartoto, Sudarso Sudarso, dan Bayu Budi Prakoso

Persepsi Guru Pamong Terhadap Kualitas Mahasiswa Calon Guru PJOK Saat Melaksanakan Program Pengelolaan Pembelajaran di Sekolah Mitra

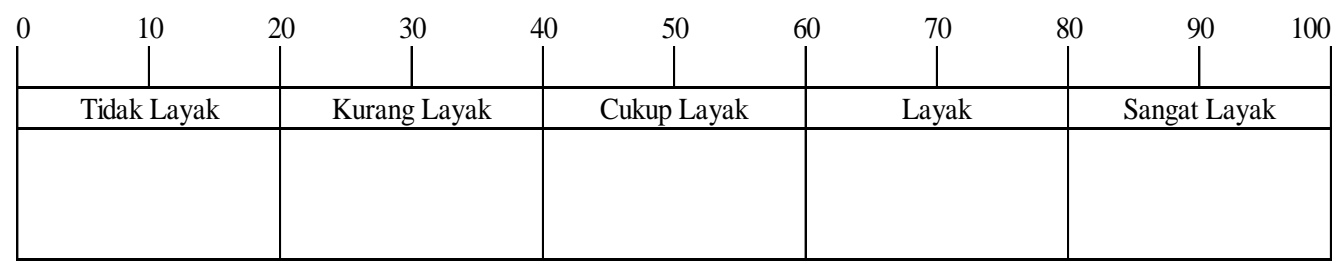

Gambar 1. Skala Ekspektasi Guru Pamong terhadap Kelayakan Mahasiswa Calon Guru PJOK saat Mengikuti PPP di Sekolah Mitra

Untuk mempermudah guru pamong dalam menilai kelayakan mahasiswa sesuai dengan skala ekspektasi mereka, maka gambar di atas dilengkapi dengan pernyataan pengantar "Tentukan nilai kelayakan untuk nama mahasiswa calon guru menjadi guru PJOK di sekolah menurut penilaian bapak/ibu guru pamong. Isikan nilai pada KOTAK sesuai dengan rentang kategori yang tersedia. Contoh: Mahasiswa mendapat nilai 68.7 masuk dalam kategori "Layak".". Guru pamong tidak cukup hanya menentukan kategori kelayakan dan besaran nilai untuk mahasiswa PPP, tetapi guru pamong wajib melengkapi nilai dengan argumen sebagai penguat dan atau bukti dalam pemberian nilai dalam kuesioner terbuka.

\section{Teknik Analisis Data}

Terdapat dua data hasil penelitian yaitu kuantitatif dan kualitatif. Data kuantitatif dianalisis menggunakan teknik statistik deskriptif. Sedangkan data kualitatif dianalisis menggunakan empat langkah, yaitu: tabulasi data, reduksi data, penyajian data, dan verifikasi/ simpulan (Sugiyono, 2008).

\section{HASIL DAN PEMBAHASAN}

\section{Hasil}

Sesuai dengan tujuan penulisan artikel, hasil penelitian mendeskripsikan tiga hal, yaitu: (1) data kelayakan mahasiswa calon guru PJOK di sekolah mitra Unesa; (2) data profil guru hebat berdasarkan persepsi guru pamong di sekolah mitra Unesa; dan (3) kualitas mahasiswa calon guru PJOK selama mengikuti PPP di sekolah mitra Unesa. Rata-rata nilai kelayakan para mahasiswa calon guru PJOK yang mengikuti PPP sebesar 80,5 (sangat layak), nilai standar deviasi sebesar 6,3, nilai 
Fifukha Dwi Khory, Setiyo Hartoto, Sudarso Sudarso, dan Bayu Budi Prakoso

Persepsi Guru Pamong Terhadap Kualitas Mahasiswa Calon Guru PJOK Saat Melaksanakan Program Pengelolaan Pembelajaran di Sekolah Mitra

terendah sebesar 70,0 (layak), nilai tertinggi sebesar 92,0 (sangat layak). Tiga mahasiswa PPP masuk dalam kategori layak dan tujuh mahasiswa masuk dalam kategori sangat layak menjadi guru PJOK di sekolah (lihat tabel 1).

Tabel 1. Nilai Kelayakan Mahasiswa Calon Guru PJOK Berdasarkan Persepsi Guru Pamong

\begin{tabular}{|c|c|c|c|c|}
\hline No. & $\begin{array}{c}\text { Kode } \\
\text { Mahasiswa }\end{array}$ & Nama Sekolah Mitra & Nilai & Kategori \\
\hline 1 & 04-07 & SMA Kemala Bhayangkari Surabaya & 70 & Layak \\
\hline 2 & 04-08 & SMA Kemala Bhayangkari Surabaya & 75 & Layak \\
\hline 3 & $08-16$ & SMKN 12 Surabaya & 82 & Sangat Layak \\
\hline 4 & $09-17$ & SMAN 14 Surabaya & 80 & Sangat Layak \\
\hline 5 & $09-18$ & SMAN 14 Surabaya & 80 & Sangat Layak \\
\hline 6 & $14-27$ & SMA 17 Agustus 1945 Surabaya & 80 & Sangat Layak \\
\hline 7 & $16-32$ & SMPN 26 Surabaya & 75 & Layak \\
\hline 8 & $19-37$ & SMK Prapanca 2 Surabaya & 92 & Sangat Layak \\
\hline 9 & $24-47$ & SMPN 21 Surabaya & 86 & Sangat Layak \\
\hline \multirow[t]{5}{*}{10} & $24-48$ & SMPN 21 Surabaya & 85 & Sangat Layak \\
\hline & & Rata-rata & 80,5 & Sangat Layak \\
\hline & & Standar Deviasi & 6,3 & \\
\hline & & Nilai Terendah & 70,0 & Layak \\
\hline & & Nilai Tertinggi & 92,0 & Sangat Layak \\
\hline
\end{tabular}

Selanjutnya, perlu diukur kualitas mahasiswa PPP dengan cara membandingkan antara kriteria profil guru hebat sesuai dengan persepsi guru pamong dan kualitas mahasiswa selama mengikuti PPP. Hasil deskripsi kriteria profil guru hebat dan kualitas mahasiswa dalam mengikuti PPP dijelaskan dari hasil analisis kualitatif (lihat tabel 2).

Tabel 2. Persepsi Guru Pamong Terhadap Profil Guru PJOK Hebat dan Kualitas Mahasiswa Calon Guru PJOK selama Mengikuti PPP

\begin{tabular}{|c|c|c|c|c|}
\hline No. & $\begin{array}{c}\text { Kode } \\
\text { Mahasiswa }\end{array}$ & $\begin{array}{l}\text { Nama } \\
\text { Sekolah } \\
\text { Mitra }\end{array}$ & Profil Guru PJOK Hebat & $\begin{array}{c}\text { Kualitas Mahasiswa Calon } \\
\text { Guru PJOK selama PPP }\end{array}$ \\
\hline 1 & 04-07 & $\begin{array}{c}\text { SMA Kemala } \\
\text { Bhayangkari } \\
\text { Surabaya }\end{array}$ & $\begin{array}{l}\text { 1. Mampu menerangkan } \\
\text { dan mengaplikasikan } \\
\text { sistem pembelajaran } \\
\text { yang sesuai dengan } \\
\text { permendikbud, } \\
\text { 2. menerapkan ilmu baru } \\
\text { 3. merancang pedoman } \\
\text { pembelajaran/ perangkat } \\
\text { pembelajaran } \\
\end{array}$ & $\begin{array}{l}\text { 1. pengelolaan/ } \\
\text { mengkondisikan siswa saat } \\
\text { KBM masih kurang } \\
\text { 2. penyampaian saat KBM } \\
\text { masih kurang jelas lugas } \\
\text { dan tegas } \\
\text { 3. perencanaan pembuatan } \\
\text { pedoman pembelajaran } \\
\text { masih kurang memahami }\end{array}$ \\
\hline
\end{tabular}


Fifukha Dwi Khory, Setiyo Hartoto, Sudarso Sudarso, dan Bayu Budi Prakoso

Persepsi Guru Pamong Terhadap Kualitas Mahasiswa Calon Guru PJOK Saat Melaksanakan Program Pengelolaan Pembelajaran di Sekolah Mitra

\begin{tabular}{|c|c|c|c|c|}
\hline No. & $\begin{array}{c}\text { Kode } \\
\text { Mahasiswa }\end{array}$ & $\begin{array}{c}\text { Nama } \\
\text { Sekolah } \\
\text { Mitra } \\
\end{array}$ & Profil Guru PJOK Hebat & $\begin{array}{l}\text { Kualitas Mahasiswa Calon } \\
\text { Guru PJOK selama PPP }\end{array}$ \\
\hline 2 & 04-08 & $\begin{array}{l}\text { SMA Kemala } \\
\text { Bhayangkari } \\
\text { Surabaya }\end{array}$ & $\begin{array}{l}\text { 1. kompetensi mengajar } \\
\text { sesuai pedoman } \\
\text { pengajaran yang sudah } \\
\text { ditentukan sesuai } \\
\text { dalam permendikbud } \\
\text { 2. mampu mengaplikasi- } \\
\text { kan sistem pembelajar- } \\
\text { an yang menarik sesuai } \\
\text { kondisi lingkungan } \\
\text { pembelajaran/sekolah }\end{array}$ & $\begin{array}{l}\text { 1. mampu menerapkan } \\
\text { sistem pembelajaran yang } \\
\text { menarik sesuai dengan } \\
\text { kondisi pembelajaran, } \\
\text { 2. pengelolaan dan } \\
\text { penguasaan kelas cukup } \\
\text { baik, } \\
\text { 3. administrasi perangkat } \\
\text { pembelajaran cukup baik }\end{array}$ \\
\hline 3 & $08-16$ & $\begin{array}{l}\text { SMKN } 12 \\
\text { Surabaya }\end{array}$ & $\begin{array}{l}\text { 1. mampu membuat } \\
\text { perangkat pembelajar- } \\
\text { an dengan baik } \\
\text { 2. menguasai kondisi kelas }\end{array}$ & $\begin{array}{l}\text { 1. rajin datang tepat waktu, } \\
\text { 2. tertarik untuk mengem- } \\
\text { bangkan diri dengan } \\
\text { belajar kepada guru senior }\end{array}$ \\
\hline 4 & $09-17$ & $\begin{array}{l}\text { SMAN } 14 \\
\text { Surabaya }\end{array}$ & $\begin{array}{l}\text { 1. memiliki kompetensi } \\
\text { akademik yang mampu } \\
\text { mengimplementasikan } \\
\text { seluruh materi } \\
\text { pembelajaran } \\
\text { 2. kemampuan memecah- } \\
\text { kan masalahan }\end{array}$ & $\begin{array}{l}\text { 1. menyampaikan materi } \\
\text { sesuai dengan pengelolaan } \\
\text { pembelajaran di kelas } \\
\text { maupun di lapangan } \\
\text { 2. peka terhadap } \\
\text { permasalahan yang ada di } \\
\text { lapangan maupun di kelas }\end{array}$ \\
\hline 5 & $09-18$ & $\begin{array}{l}\text { SMAN } 14 \\
\text { Surabaya }\end{array}$ & $\begin{array}{l}\text { 1. memiliki prestasi } \\
\text { akademik yang cukup } \\
\text { 2. kemampuan problem } \\
\text { solving untuk } \\
\text { pembelajaran di kelas } \\
\text { dan di lapangan }\end{array}$ & $\begin{array}{l}\text { 1. sangat baik dalam } \\
\text { menyampaikan materi ajar } \\
\text { 2. dapat mengelola kelas } \\
\text { dengan baik sehingga } \\
\text { siswa kondusif di lapangan } \\
\text { dan di kelas }\end{array}$ \\
\hline 6 & $14-27$ & $\begin{array}{l}\text { SMA } 17 \\
\text { Agustus } \\
1945 \\
\text { Surabaya }\end{array}$ & $\begin{array}{l}\text { 1. guru yang bisa } \\
\text { membuat siswa aktif } \\
\text { dan bisa meningkatkan } \\
\text { kebugaran jasmani } \\
\text { siswa } \\
\text { 2. menguasai semua } \\
\text { cabang olahraga yang } \\
\text { diajarkan di sekolah }\end{array}$ & $\begin{array}{l}\text { 1. menguasai materi yang } \\
\text { akan diajarkan } \\
\text { 2. mampu mengendalikan } \\
\text { dan menguasai kelas } \\
\text { 3. mempunyai dedikasi dan } \\
\text { disiplin yang baik } \\
\text { 4. bisa membuat siswa } \\
\text { berinovasi dan termotivasi } \\
\text { untuk lebih giat belajar }\end{array}$ \\
\hline 7 & $16-32$ & $\begin{array}{l}\text { SMPN } 26 \\
\text { Surabaya }\end{array}$ & $\begin{array}{l}\text { memiliki kemampuan } \\
\text { tinggi, banyak melakukan } \\
\text { inovasi, kreatif, dan } \\
\text { menyenangkan }\end{array}$ & $\begin{array}{l}\text { memiliki kompetensi sebagai } \\
\text { guru PJOK di Sekolah. }\end{array}$ \\
\hline 8 & $19-37$ & $\begin{array}{l}\text { SMK } \\
\text { Prapanca } 2 \\
\text { Surabaya }\end{array}$ & $\begin{array}{l}\text { 1. menguasai materi } \\
\text { pelajaran (profesional), } \\
\text { 2. menguasai materi dan } \\
\text { strategi pembelajaran } \\
\text { (5M dalam K-13) }\end{array}$ & $\begin{array}{l}\text { 1. berpenampilan sangat baik, } \\
\text { 2. bahasa yang digunakan } \\
\text { santun dan berbahasa } \\
\text { indonesia, } \\
\text { 3. telah menguasai materi } \\
\text { pelajaran sesuai dengan } \\
\text { kelas dan keilmuannya } \\
\text { (k.13 revisi), } \\
\text { 4. telah menguasai teknik } \\
\text { mengajar (pedagogik), } \\
\text { (strategi mengajar, evaluasi } \\
\text { mengajar, pengolaan kelas, } \\
\text { 5M, dll) }\end{array}$ \\
\hline 9 & $24-47$ & $\begin{array}{l}\text { SMPN } 21 \\
\text { Surabaya }\end{array}$ & $\begin{array}{l}\text { 1. menguasai kelas dan } \\
\text { menguasai materi } \\
\text { 2. kreatif menggunakan } \\
\text { media pembelajaran, } \\
\text { dan inovatif untuk } \\
\text { membuat atau } \\
\text { mengadakan media } \\
\text { pembelajaran }\end{array}$ & Rajin dan disiplin \\
\hline
\end{tabular}


Fifukha Dwi Khory, Setiyo Hartoto, Sudarso Sudarso, dan Bayu Budi Prakoso

Persepsi Guru Pamong Terhadap Kualitas Mahasiswa Calon Guru PJOK Saat Melaksanakan Program Pengelolaan Pembelajaran di Sekolah Mitra

\begin{tabular}{ccccc}
\hline No. & $\begin{array}{c}\text { Kode } \\
\text { Mahasiswa }\end{array}$ & $\begin{array}{c}\text { Nama } \\
\text { Sekolah } \\
\text { Mitra }\end{array}$ & Profil Guru PJOK Hebat & $\begin{array}{c}\text { Kualitas Mahasiswa Calon } \\
\text { Guru PJOK selama PPP }\end{array}$ \\
\hline 24-48 & $\begin{array}{c}\text { SMPN 21 } \\
\text { Surabaya }\end{array}$ & $\begin{array}{c}\text { kreatif dalam } \\
\text { menggunakan media } \\
\text { pembelajaran, } \\
\text { 2. inovatif dalam membuat } \\
\text { media pembelajaran }\end{array}$ & Rajin dan disiplin \\
\hline
\end{tabular}

Menurut persepsi para guru pamong, kriteria guru PJOK hebat yang diperlukan sekolah saat ini adalah mereka yang memiliki prestasi akademik, menguasai perkembangan kurikulum 2013, menguasai materi ajar, memiliki keterampilan pengelolaan kelas, keterampilan pemecahan masalah, kreatif dan inovatif. Sedangkan menurut persepsi guru pamong, kualitas mahasiswa PPP calon guru PJOK telah memiliki kemampuan yang cukup dalam mengelola kelas, membuat RPP K-13, menguasai teknik mengajar, update pengetahuan tentang $\mathrm{K}-13$, kemampuan mengembangkan diri tinggi, memiliki dedikasi, dan sikap disiplin tinggi.

\section{Pembahasan}

Hasil penelitian dapat menjelaskan bahwa secara sederhana guru pamong memberikan pengakuan sesuai dengan persepsi mereka terhadap kualitas mahasiswa calon guru PJOK yang didampingi. Penilaian ini berguna dalam memberikan gambaran kepada LPTK dalam mengetahui kualitas calon luaran sebagai guru PJOK. Penilaian semacam ini berada pada tahap dua dalam proses evaluasi kompetensi mahasiswa di PT. Di Eropa, berkembang sistem penilaian efektivitas pendidikan di PT melalui tiga fase, yaitu: fase-1 evaluasi kompetensi sesuai tuntutan kurikulum (situasi ideal), fase-2 evaluasi proses pembelajaran dan kompetensi yang diperlukan lapangan (situasi nyata), dan fase-3 evaluasi konkret pada aspek-aspek yang berhubungan dengan pembelajaran (Bergsmann, Schultes, Winter, Schober, \& Spiel, 2015). Melalui penilaian semacam ini, mahasiswa calon guru PJOK dan PT diharapkan benarbenar mngetahui bahwa kualitas calon luaran di lapangan memiliki derajat kelayakan sesuai kebutuhan lapangan.

Kualitas penilaian berdasarkan persepsi memang memiliki keberagaman sesuai dengan tingkat objektivitas dan pemahaman penilai terhadap objek yang dinilai. Asumsi yang dibangun adalah setiap guru SPORTIF, 4 (1) 2018 | 38-53 
pamong memiliki skala penilaian masing-masing yang telah disesuaikan dengan kebutuhan sekolah masing-masing. Idealnya, hasil penilaian yang diberikan guru adalah penilaian atas dasar kebutuhan lapangan.

Selanjutnya, proses kolaborasi guru pamong dan mahasiswa calon guru PJOK selama mengikuti PPP menjadi kunci kebenaran asumsi yang dibangun karena menjadi bukti keberhasilan pelaksanaan PPP. Seharusnya, semakin baik kolaborasi guru pamong sebagai mentor dengan mahasiswa calon guru PJOK (yang dimentori), maka akan semakin baik pelaksanaan PPP. Kolaborasi ini akan semakin memberikan pengalaman kepada mahasiswa calon guru PJOK terkait pembelajaran dan mengenal lingkungan sekolah (Hill \& Brodin, 2004) yang menjadi tujuan utama pelaksanaan PPP. Akhirnya, ujung dari kegiatan PPP adalah memberikan gambaran kepada para stake holder tentang kemampuan output LPTK, sedangkan mahasiswa memiliki pengalaman di sekolah untuk mengasah kompetensi sebagai guru, sedangkan LPTK mendapatkan masukan berupa kriteria guru yang hebat sesuai dengan kebutuhan lapangan.

Hasil penelitian menunjukan bahwa, paling tidak ada enam karakteristik guru PJOK yang hebat sesuai dengan kebutuhan lapangan, yaitu: prestasi akademik, penguasaan kurikulum 2013, penguasaan materi ajar, keterampilan mengelola kelas, kemampuan memecahkan masalah, kreatif, dan inovatif. Prestasi akademik para guru PJOK selama belajar di PT menjadi satu tolok ukur yang memang perlu diperhatikan dalam menentukan kualitas guru ke depannya. Umumnya, ukuran satu-satunya yang dipertimbangkan diawal rekrutmen sekolah adalah Indeks Prestasi Akademik (IPK) yang tertera dalam transkip nilai. IPK dapat menjadi ukuran kompetensi mahasiswa sebagai hasil belajar selama mengikuti perkuliahan di PT. Akan tetapi, seharunya ukuran tersebut bukan satusatunya bahan pertimbangan yang dapat digunakan dalam menentukan kualitas para calon guru PJOK saat melamar menjadi guru di sekolah, untuk mendapatkan kualitas guru PJOK yang hebat perlu juga diperhatikan kondisi fisik pelamar (Alysia, Caputo, \& Farley, 2005). 
Penampilan fisik menjadi representasi diri calon guru PJOK yang dapat menjaga status gizi normal dan menjaga bentuk tubuh tetap fit. Hal tersebut menjadi penting karena guru PJOK memiliki tugas pokok sebagai promotor hidup sehat dimanis di lingkungan sekolah (Giriwijoyo, 2012).

Menguasai perkembangan kurikulum 2013 menjadi hal wajib bagi para guru PJOK untuk dapat selalu mengikuti perkembangan kurikulum secara berkelanjutan. Sudah menjadi anggapan umum bahwa pergantian pemerintah selalu diikuti dengan kurikulum baru yang akhirnya melahirkan banyak keluhan dari kalangan guru yang terlanjur nyaman dengan kebiasaan menerapkan kurikulum lama (Suroto, 2017a). Untuk memenuhi target berupa update penguasaan perkembangan kurikulum guru perlu senantiasa memiliki kemauan untuk mengembangkan diri yang melibatkan pengawas sekolah, kepala sekolah, dan guru sejawat (Suroto, 2016). Bimbingan supervisor dan teman sejawat diharapkan memberikan kontribusi dalam memacu guru untuk belajar sehingga selain penguasaan terhadap perkembangan kurikulum meningkat, penguasaan terhadap materi ajar juga dapat berkembang akibat diskusi dan tukar pendapat terkait pembelajaran dengan teman sejawat. Hal ini sangat membantu guru PJOK dalam meningkatkan penguasaan dan pengembangan materi ajar untuk pembelajaran yang efektif.

Menguasai materi ajar menjadi kunci penting untuk guru dapat menyampaikan materi dengan lantang dan jelas kepada peserta didik. Guru yang menguasai materi ajar terlihat mampu bercerita tentang bahan ajarnya dari berbagai sisi dan dengan berbagai cara, sehingga dapat menjawab keraguan siswa tentang kebenaran gerak yang sedang dipelajarinya (Suroto, 2008). Penguasaan materi ajar adalah termasuk guru PJOK menguasai berbagai keterampilan dalam berbagai cabang olahraga yang menjadi materi ajar dalam kurikulum yang berlaku. Selain itu, materi ajar yang dikembangkan wajib memiliki kontribusi dalam mengembangkan empat ranah, yaitu sikap spiritual, sosial, pengetahuan, dan keterampilan (Menteri Pendidikan dan Kebudayaan Republik Indonesia, 2016). Sikap spiritual dan sosial didapatkan melalui pendidikan 
karakter yang di dalam pembelajaran PJOK ditempuh melalui pembiasaan sikap sportif dari internalisasi aktivitas gerak dan olahraga (Suroto, 2017b; Yuliawan, 2016). Ranah pengetahuan dapat berupa dampak aktivitas gerak terhadap kesehatan, berbagai cabang olahraga, dan keuntungan lain dari olahraga. Sedangkan untuk keterampilan dapat berupa latihan kebugaran, keterampilan cabang olahraga, atau permainan-permainan sederhana dan atau tradisional yang dapat meningkatkan keterampilan gerak dasar terutama pada siswa sekolah dasar (Hanief \& Sugito, 2015; Setyorini, Suroto, \& Indahwati, 2017).

Memiliki keterampilan pengelolaan kelas adalah berkaitan dengan kemampuan guru dalam menguasai keterampilan mengajar yang meliputi 12 keterampilan, yaitu: (1) menyiapkan pembelajaran; (2) membuka pembelajaran; (3) mengelola waktu dan arena pembelajaran; (4) mengelola pemanasan dan pendinginan; (5) menempatkan diri; (6) membuat perintah; (7) memonitor perintah; (8) memberi umpan balik; (9) mencatat kemajuan belajar siswa; (10) bertanya/refleksi/ menggali pengalaman belajar siswa; (11) menutup pembelajaran (12) mengevaluasi diri (Suroto \& Khory, 2013). Evaluasi diri menjadi salah satu cara untuk meningkatkan keterampilan mengajar guru yang dapat ditempuh dengan cara melihat kembali rekaman proses pembelajaran berkali-kali sampai seluruh indikator keterampilan mengajar guru terpenuhi (Prakoso, 2015). Dengan memiliki keterampilan mengajar yang mumpuni, diharapkan dapat memecahkan masalah-masalah yang dihadapi oleh guru.

Keterampilan pemecahan masalah yang wajib dimiliki oleh guru adalah pemecahan masalah belajar siswa dalam kelas, baik permasalahan pembelajaran dalam ruangan kelas maupun kelas yang dilaksanakan di lapangan. Pemecahan masalah ini memiliki implikasi kepada pemenuhan kebutuhan belajar peserta didik yang berlandaskan pada standar-standar yang telah dirumuskan dalam kurikulum yang berlaku. Pemerintah melalui buku panduan pembelajaran untuk tingkat satuan pendidikan telah memberikan anjuran penerapan model-model pembelajaran yang sesuai untuk kebutuhan belajar di abad 21 dalam 
kurikulum 2013 (Ministry of National Education of Republic of Indonesia, 2016). Tetapi, penyiapan pembelajaran sesuai anjuran kurikulum 2013 menjadi hal sulit bagi sebagian guru, kecuali guru kreatif dan inovatif.

Kreatif dan inovatif merupakan dua hal yang akan menjadikan guru dapat menghadirkan kebaruan dalam setiap pembelajaran untuk menjawab tantangan yang diberikan oleh perkembangan kurikulum yang berlaku. Selain itu, guru yang kreatif dan inovatif dapat menciptakan banyak aktivitas pembelajaran sepanjang alokasi waktu pembelajaran yang diberikan. Sehingga tidak ada waktu terbuang yang menjadikan siswa tidak terlibat aktif dalam pembelajaran. Fokus aktivitas belajar siswa dalam pembelajaran PJOK oleh guru kreatif dan inovatif, yaitu: kecukupan belajar gerak siswa dan konstruksi nilai-nilai dalam olahraga (Suroto et al., 2007). Kecukupan belajar gerak menjadi fokus penting dalam PJOK sebagai satu-satunya mata pelajaran yang diharapkan dapat mempromosikan hidup sehat melalui hidup aktif (Setyorini et al., 2017). Tidak hanya itu, melalui PJOK siswa diajarkan untuk membiasakan diri dalam bersikap baik dengan cara menginternalisasi nilai-nilai olahraga (Suroto, 2017b).

\section{KESIMPULAN DAN SARAN}

Pelaksanaan PPP untuk mahasiswa calon guru PJOK menjadi kegiatan yang sangat berharga dalam memberikan pengalaman untuk mengenal lingkungan sekolah, menerapkan ilmu, dan bersosialisasi dengan masyarakat pendidikan. Kolaborasi antara mahasiswa dan guru pamong menjadi kunci sukses pelaksanaan PPP. Guru pamong dianggap memiliki kapasitas yang cukup untuk memberikan penilaian terhadap kinerja mahasiswa selama mengikuti PPP. Untuk itu, persepsi guru pamong dianggap layak untuk mencapai tujuan penulisan artikel ini sehingga dapat disimpulkan tiga hal, yaitu: (1) para mahasiswa calon guru PJOK memiliki nilai yang sangat layak untuk menjadi guru PJOK di sekolah; (2) profil guru PJOK yang hebat untuk sekolah adalah guru yang memiliki kemampuan akademik mumpuni, menguasai perkembangan 
Fifukha Dwi Khory, Setiyo Hartoto, Sudarso Sudarso, dan Bayu Budi Prakoso

Persepsi Guru Pamong Terhadap Kualitas Mahasiswa Calon Guru PJOK Saat Melaksanakan Program Pengelolaan Pembelajaran di Sekolah Mitra

kurikulum terbaru, menguasai materi ajar, memiliki keterampilan pengelolaan kelas yang baik, keterampilan memecahkan masalah pembelajaran, kreatif dan inovatif; dan (3) mahasiswa calon guru PJOK memiliki kemampuan yang cukup dalam mengelola kelas, membuat RPP $\mathrm{K}-13$, menguasai teknik mengajar, update pengetahuan tentang $\mathrm{K}-13$, kemampuan mengembangkan diri tinggi, memiliki dedikasi, dan sikap disiplin yang tinggi. Hasil penelitian ini secara sekilas telah mampu mendeskripsikan kualitas mahasiswa calon guru PJOK dalam mengikuti PPP, akan tetapi jumlah subjek penelitian yang sedikit akibat kebersediaan subjek yang rendah dalam pengikuti proses penelitian menjadi batasan dalam proses generalisasi hasil terhadap populasi. Untuk mendapatkan gambaran penuh terhadap kinerja mahasiswa calon guru dalam mengikuti PPP, penelitian selanjutnya diharapkan dapat melibatkan jumlah subjek yang lebih komprehensif untuk mewakili populasi atau bahkan dapat dilakukan secara total populasi.

\section{DAFTAR PUSTAKA}

Alysia, J., Caputo, J. L., \& Farley, R. S. (2005). Physical Description and Job Attainment in Physical Education. Physical Educator, 62(2), 96102. Retrieved from https://e-resources.perpusnas.go.id:2057/ docview/233002952/fulltextPDF/94D571096CD244AAPQ/1 ?accounti $d=25704$.

Bandura, A. (2006). Guide for constructing self-efficacy scales. In Selfefficacy beliefs of adolescents (pp. 307-337). Information Age Publishing. https://doi.org/10.1017/CBO9781107415324.004.

Barney, D., \& Pleban, F. (2006). Pre-Service Physical Education Teacher's Perceptions of Teaching Before and After a Semester Long Elementary Physical Education Practicum Experience. Physical Educator, 63(1), 46-52. Retrieved from https://eresources.perpusnas.go.id:2057/docview/232999119/fulltextPDF/740 D7899C63149B1PQ/1 ?accountid=25704.

Bergsmann, E., Schultes, M.-T., Winter, P., Schober, B., \& Spiel, C. (2015). Evaluation of competence-based teaching in higher education: From theory to practice. Evaluation and Program Planning, 52, 1-9. https://doi.org/10.1016/j.evalprogplan.2015.03.001.

Faikhamta, C., \& Clarke, A. (2018). Thai Cooperating Teachers' Motivations and Challenges in Supervising Student Teachers During 
Fifukha Dwi Khory, Setiyo Hartoto, Sudarso Sudarso, dan Bayu Budi Prakoso

Persepsi Guru Pamong Terhadap Kualitas Mahasiswa Calon Guru PJOK Saat Melaksanakan Program Pengelolaan Pembelajaran di Sekolah Mitra

Their Internship Program. Kasetsart Journal of Social Sciences, 1-7. https://doi.org/10.1016/j.kjss.2017.12.018.

Fransson, G., \& K. McMahan, S. (2013). Exploring research on mentoring policies in education. International Journal of Mentoring and Coaching in Education, 2(3), 218-232. https://doi.org/10.1108/IJMCE-05-20130031.

Giriwijoyo, H. Y. S. S. (2012). Ilmu Faal Olahraga (Fisiologi Olahraga) (1st ed.). Bandung: PT Remaja Rosdakarya.

Hanief, Y. N., \& Sugito. (2015). Membentuk Gerak Dasar Pada Siswa Sekolah Dasar Melalui Permainan Tradisional. Jurnal SPORTIF : Jurnal penelitian Pembelajaran, 1(1), 60-73. Retrieved from http://ojs.unpkediri.ac.id/index.php/pjk/article/ view/575/433.

Helgevold, N., Næsheim-Bjørkvik, G., \& Østrem, S. (2015). Key focus areas and use of tools in mentoring conversations during internship in initial teacher education. Teaching and Teacher Education, 49, 128137. https://doi.org/10.1016/J.TATE.2015.03.005.

Hill, G., \& Brodin, K. L. (2004). Physical Education Teachers' Perceptions of the Adequacy of University Coursework in Preparation for Teaching. Physical Educator, 61(2), 75-87. Retrieved from https://eresources.perpusnas.go.id:2057/docview/233006118/fulltextPDF/C61 CD88BAB3D42E8PQ/1 ?accountid=25704.

Indonesian Government. Undang-Undang Republik Indonesia Nomor 14 tahun 2005 tentang Guru dan Dosen (2005). Retrieved from http://ditjenpp.kemenkumham.go.id/database-peraturan/peraturanmenteri.html.

Indonesian Government. Peraturan Pemerintah Republik Indonesia nomor 74 tahun 2008 tentang Guru (2008). Retrieved from http://peraturan.go.id/search/download/11e44c4f52a0fe20a40331323 2303239.html.

Marli, S. (2011). Supervisi Klinis Bagi Calon Guru dalam Program Pengalaman Lapangan (PPL). Visi Ilmu Pendidikan, 5(2), 432-444. https://doi.org/10.26418/jvip.v5i2.58.

Menteri Pendidikan dan Kebudayaan Republik Indonesia. Permendikbud RI No. 24 Tahun 2016 tentang Kompetensi Inti dan Kompetensi Dasar Pelajaran Pada Kurikulum 2013 Pada Pendidikan Dasar dan Pendidikan Menengah (2016). Retrieved from http://peraturan.go.id/permen/kemendikbud-nomor-24-tahun-2016tahun-2016.html.

Ministry of National Education of Republic of Indonesia. Peraturan Menteri Pendidikan Nasional Republik Indonesia Nomor 16 tahun 2007 tentang Standar Kualifikasi Akademik dan Kompetensi Guru (2007). 
Fifukha Dwi Khory, Setiyo Hartoto, Sudarso Sudarso, dan Bayu Budi Prakoso

Persepsi Guru Pamong Terhadap Kualitas Mahasiswa Calon Guru PJOK Saat Melaksanakan Program Pengelolaan Pembelajaran di Sekolah Mitra

Retrieved from http://vervalsp.data.kemdikbud.go.id/ prosespembelajaran/file/Permendiknas No 16 Tahun 2007.pdf.

Ministry of National Education of Republic of Indonesia. (2016). Panduan Pembelajaran untuk Sekolah Menengah Pertama (1st ed.). Jakarta: Direktorat Jenderal Pendidikan Dasar dan Menengah. Retrieved from http://ditpsmp.kemdikbud.go.id.

Prakoso, B. B. (2015). Upaya Peningkatan Kualitas Proses Belajar Mengajar PJOK melalui Evaluasi Diri Guru. In Optimalisasi Hasil-Hasil Penelitian dalam Menunjang Pembangunan Berkelanjutan (pp. 510523). Makassar.

Şen, A. I. (2010). Effects of peer teaching and microteaching on teaching skills of pre-service physics teachers. Egitim ve Bilim, 35(155), 78-88. Retrieved from https://search.proquest.com/openview/50bb9a17 f8480e639ad2c1b92a45220b/1 ?pq-origsite=gscholar\&cbl=1056401.

Setyorini, Suroto, \& Indahwati, N. (2017). First Grade Primary School Students' Physical Activity Level on Physical Education Subject through Live Life Well at School Program. IOP Conf. Series: Materials Science and Engineering, 180(12178), 1-6. https://doi.org/10.1088/1757-899X/180/1/012178.

Sugiyono. (2008). Memahami Penelitian Kualitatif. Bandung: Alfabeta.

Suroto. (2008). Tiga Belas Jurus Mengelola Pembelajaran Penjasorkes sehingga Menarik dan Produktif. In Bugar, cerdas, dan berprestasi melalui manajemen pembelajaran penjasorkes yang professional di sekolah (pp. 1-12). Surabaya.

Suroto. (2016). Peran Sekolah dan Perguruan Tinggi dalam Mewujudkan Guru PJOK Profesional yang Pembelajar. In Konvensi Nasional Pendidikan Indonesia (KONASPI) VIII Tahun 2016 (pp. 1425-1430). Jakarta: Universitas Negeri Jakarta. Retrieved from http://seminars.unj.ac.id/konaspi/file/Prosiding KONASPI VIII 2016.pdf.

Suroto. (2017a). Inovation Teaching Method for Physical Education Teacher in Indonesia. In Proceeding 2nd International Conference of Sport Science (pp. 94-107). Surabaya: Unesa University Press.

Suroto. (2017b). Peran PJOK dalam Membangun Karakter Siswa. In Menuju Generasi Yang Sehat Dan Berprestasi Dalam Bidang Olahraga Melalui Pendidikan Karakter Berlandaskan Aswaja. Bojonegoro: Universitas Nahdlatul Ulama.

Suroto, \& Khory, F. D. (2013). Peningkatan Keterampilan Mengelola Pembelajaran Siswa Aktif melalui Pendekatan Lesson Study (Studi pada Guru PJOK SDN di Kecamatan Taman Sidoarjo). Surabaya. 
Suroto, Maksum, A., Kartiko, D. C., Nurhayati, F., Subagyo, Priambodo, An., ... Wijaya, M. A. (2007). Buku Panduan Pelaksanaan Model Pembelajaran Inovatif Pendidikan Jasmani, Olahraga, dan Kesehatan IU-07-1. Surabaya.

Tim PPP. (2017). Buku Panduan PPP. Surabaya: Lembaga Pengembangan Pembelajaran dan Penjamin Mutu Unesa.

Ward, P. (2013). The Role of content knowledge in conceptions of teaching effectiveness in physical education. Research Quarterly for Exercise and Sport, 84(4), 431-440. https://doi.org/10.1080/02701367.2013.844045.

Yuliawan, D. (2016). Pembentukan Karakter Anak Dengan Jiwa Sportif Melalui Pendidikan Jasmani Olahraga dan Kesehatan. Jurnal SPORTIF : Jurnal Penelitian Pembelajaran, 2(1), 101-112. Retrieved from http://ojs.unpkediri.ac.id/index.php/ pjk/article/view/661/469. 